\title{
OIL PRODUCTION AND THE PROBLEMATIC OF WATER POLLUTION IN THE NIGER DELTA: A STUDY OF SELECTED COMMUNITIES IN BAYELSA STATE
}

\section{Kelly Bryan Ovie Ejumudo}

Novena University, Ogume, Nigeria.

E-mail: drkellypaulovieejumudo@yahoo.com

\author{
Ogochukwu Harrison Amede \\ Delta State University, Abraka, Nigeria \\ E-mail: amedeharrison@yahoo.com
}

\begin{abstract}
This study examines the problematic of oil production and water pollution in selected oil-bearing communities in Bayelsa State. The design of the study was descriptive survey. The instrument used for data collection was questionnaire. The data were analyzed using chi-square. The findings of the study revealed that there is a significant relationship between the role of the Nigerian State, multinational oil companies as well as the community leadership and the negative effects of water pollution on the health, occupation/economic and the livelihood standard/poverty level of the people of the oil-bearing communities in Bayelsa State. The study recommended among others that the multi-layered levels of government should formulate and genuinely implement policies that will mitigate the effects of water pollution on the health, economic and livelihood status of the people and the multinational oil conglomerates should be truly committed to integrated policies and strategies that will close the developmental gaps in the Niger Delta Region.
\end{abstract}

Key-words: oil production, water pollution, Niger Delta, Bayelsa State, communities.

\section{Introduction}

Globally, development has become part of society, whether in the developed or developing world. Development is also multi-faceted and multidimensional cutting across all sectors. Development is equally transboundary with its systems, processes, costs and benefits affecting different societies, their environments including plants, animals and human beings that 
inhabit them. Human beings that are central to the development agenda and process are fortunately and unfortunately the major beneficiaries and sufferers (Ejumudo 2015).

In Nigeria, the major sector where development has taken place is oil. And since the quest for development appears unending in Nigeria, the many-sided effects (both positive and negative) are inevitably resident with us. In fact, since the discovery of oil in commercial quantities at Oloibiri in Nigeria in 1956, oil exploration and production has continued without ceasing and the sector has remained the mainstay in the largely mono-product rentier economy that Nigeria represents (Humphrey 2015). The treasure-base for oil exploration and production process and activities in Nigeria is the Niger Delta region.

All the same, in the face of the petroleum and allied laws, policies and the attendant actions and operations of the Nigerian state, the multi-national oil conglomerates and their local partners have through their oil exploration, production and transportation activities contributed to the destruction of the Niger Delta including water. Arguably, water is an important constituent of biotic community (Narayanan 2017) and it is biologically necessary for life and therefore plays a vital and pervasive role in the health and welfare of a modern economy (Field 2015). Apart from the fact that water is essential for nearly every human efforts and enterprise, more than any other environmental factor, its availability of water determines the location and activities of humans on earth (Cunningham 2016). In fact, the importance of water quality for human existence and health cannot be overemphasized.

It is instructive to note that the inevitability of oil production especially in a developing country like Nigeria largely due to the quest for development has made water pollution which includes the alteration of the properties of water and the presence of some inorganic, organic, biological, radiological or physical foreign substance in the water to be common place and part of society. According to Narayanan (2017), water pollution tends to degrade its quality and render it unfit or less fit for all purposes. King (2016) also posited that water pollution as a result of the activities of man makes it less suitable for all or any of the purposes for which it would be suitable in its natural state, while Tietenberg (2015) opined that water pollution renders it unusable or dangerous as regards food, human and animal health, industry, agriculture, fishing or leisure pursuits. Thus, water pollution reduces the amount of pure fresh water that is available for such necessities as drinking, cooking and cleaning and for recreation activities.

The factors responsible for water pollution may be artificial or natural. However, more than natural factors, it is the unprecedented industrial 
production rate that is responsible for the scarcity of pure drinking water (Ejumudo 2011). Despite the fact that water has become a scare commodity today on account of the innumerable ways in which human beings pollute it, human beings are making increasing demands on water and industrial activities including oil exploration and production, agriculture, irrigation, mining, power generation and the concentration of millions of people in cities and towns.

While the above factors have contributed to the escalating and worrisome levels of water pollution in the Nigeria's Niger Delta, several studies have, in fact, shown that crude oil production and spillage polluted the environment including land and water. For instance, Asia et al. (2007) examined the effects of petroleum exploration and production operations on the heavy metal contents of soil and ground water in the Niger Delta. The result of the study showed that the water was polluted by lead, the $\mathrm{pH}$ of the water samples was also found to deviate significantly from DPR limits and W.H.O. standard for potable water. Olusiyi (2009) explored the effects of oil spillage on the socioeconomic activities of the people and the environment in some communities in the Niger Delta and the findings showed that there is a strong relationship between the volume of oil spilled and the area coverage and a higher concentration of heavy metals.

In a similar vein, Isola (2014) investigated the impact of oil production on human condition in Nigeria and the study revealed that oil production worsened environmental degradation and adversely impacted on infant mortality rate, while it positively affected life expectancy. Raffia and Muhammad (2014) also examined the major sources of water pollution, water resources policies and challenges to improve water quality in Malaysia and the findings indicate that the major problem associated with water pollution is that human heart and kidneys can be adversely affected if polluted water is consumed regularly. Nizel and Nazrul (2015) equally investigated water pollution and its impact on the human health and the results clearly indicated that the water quality of Turag river may not be in a position to sustain the aquatic life and not suitable for using domestic purpose.

In like manners, Akankali and Nwafili (2017) evaluated the impact of crude oil pollution on aquaculture and the study established that crude oil pollution has adverse and severe socio-economic impacts on fish farming and that crude oil pollution led to increased fish mortality rates, reduced yield and general poor quality of cultured fishes. Abosede (2017) equally examined the effect of oil exploitation on the socio-economic life of the Ilaje-Ugbo people of Ondo State and the result showed that oil exploitation brought about environmental degradation which depleted the fishing and farming output 
and led to subsequent loss of income base and poverty. Afonughe and Mukoro (2017) also investigated the impact of oil exploitation on the socio-economic life of Orogun community and the study revealed that the activities of crude oil exploration companies are impacting negatively on the development of the community.

Specifically, one of the many areas worse hit by oil production and related activities and operations, apart from devastation in the form of air pollution and soil degradation is water pollution. Notably, the importance of water to development is evident in the critical role it plays in health and sanitation, education, food production and security, fish farming, diet and livelihood, industrialization, manufacturing, laboratory science and technological advancement, trade and commerce, entrepreneurship, occupational growth and production. Moreover, the critical link that water provides if the environment is to perform its functions particularly in the supply of resources for development purposes cannot be over-emphasized. The contention of this study is that despite the utilitarian value of the water resource for development at all levels: individual, local, national and international and the inevitability of the exploitation of the environment and the use and possible misuse of its resources for development with consequential implications including water pollution, poor sanitary condition, deteriorating health and socio-economic dislocation due to occupational challenges and poverty, multi-national oil companies, community leaders and the government have largely failed to effectively manage the challenges of oil production and water pollution in Nigeria's Niger Delta.

\section{Statement of the Problem}

The interface between the agent of development (oil production) and the environment of the Niger Delta, particularly the Bayelsa State oil-bearing communities (environments) have many-sided negative effects including air pollution and deterioration, social-degradation and particularly water pollution that is the focus of this study. The above interface has also produced benefits mainly in the form of revenue derived from export of crude oil and its investment in infrastructural development. The contention in this study is that the while water pollution, the product of the inter-linkage between oil production (agent of development) and the environment where oil is exploited is a problem and a cost, the major problem is the failure of the Nigerian State (Federal and the Bayelsa State Governments in this instant case), multi-national companies and the community leadership to effectively manage the inevitable result of the interface (water pollution) through 
adequate investments in the provision of clean water, health facilities and alternative sources of income and livelihood.

The above poor management of the water pollution resulting from oil production activities in Bayelsa State, this study further argues has seriously affected the health, occupation/economic status and the livelihood of the people in the oil-bearing communities. This study therefore examines the problematic of oil production and water pollution in selected oil-bearing communities in Bayelsa State.

\subsection{Objectives of the Study}

The general objective of the study is to examine the problematic of oil production and water pollution in selected oil-bearing communities in Bayelsa State, while the specific objectives are to:

Assess the role of the Nigerian State and the community leadership in the negative effect of water pollution on the health of the people of the oil-bearing communities in Bayelsa State.

Examine the role of the Nigerian state, multinational companies and the community leaders in the negative impact of water pollution on the occupation/economic status of the people of the oil-bearing communities in Bayelsa State.

Examine the role of the Nigerian state, multinational companies and the community leaders in the negative impact of water pollution on the livelihood standards/poverty level of the oil-bearing communities in Bayelsa State.

\subsection{Research Hypotheses}

The following research hypotheses were formulated to guide the study:

- There is no significant relationship between the role of the Nigerian State, multinational companies and the community leadership and the negative effect of water pollution on the health of the people of the oil-bearing communities in Bayelsa State.

- There is no significant relationship between the role of the Nigerian state, multinational companies and the community leadership and the negative impact of water pollution on the occupation/economic status of the people of the oil-bearing communities in Bayelsa State.

- There is no significant relationship between the role of the Nigerian state, multinational companies and the community leadership and the negative impact of water pollution on the livelihood standards/poverty level of the oilbearing communities in Bayelsa State. 


\subsection{Empirical Studies on Oil Production and Water Pollution}

Osumgborogwu, Okoro, and Oduaro (2018) assessed social effects of crude oil exploration and extraction activities in some selected communities in Egbema of Imo State. To achieve this, 150 copies of well-structured questionnaire were distributed to residents of the study area. Of this number, 141 copies were correctly filled and returned, thus, representing 94 percent of respondents. Ten oral interviews were also conducted with identified heads of households. The results as presented showed that social activities in the community have not been affected by crude oil production. However, some hostile behaviours such as youth restiveness is as a result of demand for compensation/payment from oil companies operating in the study area were observed. It is therefore recommended that further research be carried out to assess security effects of crude oil production.

Abosede (2017) examined the effect of oil exploitation on the socioeconomic life of the Ilaje-Ugbo people of Ondo State, Nigeria. Primary data were obtained through in-depth interviews, Focus Group Discussions (FGD), and a questionnaire. Oil exploitation, through environmental degradation, depleted the fishing and farming output, resulting in the subsequent loss of income base, thereby accentuating poverty, which in turn created divisive tendencies leading to endemic social conflict. Nigerian government top-down approach to the development of the oil-bearing areas has not been peoplecentered, participatory, and sustained. Any effort to eradicate poverty in the oil-bearing areas must seek to revive the traditional economic activities. Providing viable employment opportunities for the people and channelling their energies into the development of sustained livelihoods can reduce tensions and conflict in the Niger Delta region.

Afonughe and Mukoro (2017) also investigated the impact of oil exploitation on the socio-economic life of Orogun community, an Oil Producing Community in Delta State, Nigeria. The states in the Niger Delta have the largest concentrations of these oil deposits. Expectedly, this is supposed to translate into economic prosperity for these "fortunate" states and communities. Sadly, the reverse is the case. There have been cries of marginalization, environmental pollution, climate change, unemployment, prevalence of sicknesses and diseases due to the activities of crude oil exploitation in these oil producing communities. It is against this backdrop that this study was conducted. Orogun community was selected as a case study because of its prominence in the comity of oil producing communities in Delta State, and also for the fact that despite its enormous contributions to Nigeria's GDP, very little or no research has been conducted to ascertain the negative impact of oil exploration on its socio-economic life. The study 
identified that the activities of crude oil exploration companies are impacting negatively on the development of the community. Farmlands have been rendered infertile, thereby hampering agricultural output and productivity. Rivers and streams have been polluted as a result of oil spillage, leading to the reduction in the availability of fishes and other aquatic products, resulting in untold hardships being experienced by the indigent populace. In order to ameliorate the situation, this paper recommends that a proper legislation and a regulatory framework guiding the operations of the oil exploration companies should be put in place.

Mehtab, Muhammad, Asma, Sidra, Nayab, Sharon, and Jaweria (2017) equally explored water pollution and human health. The data that was used for the study was obtained and compiled through a thorough review of various published research articles of international reputed journal and relevant books. Water covers about 70\% Earth's surface. Safe drinking water is a basic need for all humans. The WHO reports that $80 \%$ diseases are waterborne. Industrialization, discharge of domestic waste, radioactive waste, population growth, excessive use of pesticides, fertilizers and leakage from water tanks are major sources of water pollution. These wastes have negative effects on human health. Different chemicals have different affects depending on their locations and kinds. Bacterial, viral and parasitic diseases like typhoid, cholera, encephalitis, poliomyelitis, hepatitis, skin infection and gastrointestinal are spreading through polluted water. It is recommended to examine the water quality on regular basis to avoid its destructive effects on human health. Domestic and agriculture waste should not be disposed of without threating.

Akankali and Nwafili (2017) evaluated the impact of crude oil pollution on aquaculture, with the objective of assessing its impacts and the extent of the identified impacts socioeconomically. Data were obtained from a total of 150 fish farmers in five communities of Gokana LGA of Rivers State, Nigeria using structured questionnaires. The study established that crude oil pollution has adverse and severe socio-economic impacts on fish farming. The results of the study also showed that, crude oil pollution led to increased fish mortality rates, reduced yield and general poor quality of cultured fishes. The Kendall's coefficient of concordance, $\mathrm{W}$ was 0.97 , indicating high degree of agreement among respondents. Recommendations based on the findings include the provision of more accessible means of information about the adverse consequences of oil pollution to the local communities in particular, educating the people on the socio-economic impact of crude oil pollution and the effects of consuming aquatic resources from polluted waters on the health of humans. Best practices for spill and pollution abatement/prevention 
including quick response to spill site and mobilizing communities through Global Memorandum of Understanding (GMOU) model to take more direct responsibility for monitoring oil theft and sabotage were recommended to be implemented by the crude oil producing companies within the Niger Delta region, as a means of abating the negative effects of crude oil pollutants adversely impacting aquaculture.

Imoukhuede and Afuye (2016) assessed water pollution and its effect on water consumption in Akure. The research focuses primarily on the causes, consequences and ways of mitigating the ongoing fresh water pollution problems among Akure communities. Surface water quality of River Ala, which cut across the town of Akure was assessed and three locations (3) were chosen spatially to reflect a consideration of all possible human activities capable of changing the quality of river water. Water samples were analyzed for physio-chemical parameters and it was observed that variations exist in the quality of the sampled waters and impaired to different degrees using WHO drinking water standards for the selected parameters. Leo road (Ala 3) has the highest dissolved solids, which shows that the dumping of waste to the water bodies might have caused the higher occurrence; the PH was low in Ala 3 and high in Ala 1 (Oke-Ijebu) with 6.9 and 7.4 respectively. The water is coloured, total alkalinity total hardness, iron and turbidity were found to be above the WHO standard, therefore not suitable for domestic use.

Nizel and Nazrul (2015) investigated water pollution and its impact on the human health. This study was conducted to find out the pollution situation of Turag River of urban Dhaka, the capital city of Bangladesh and the health problem of the surrounding residents. The results clearly determine that the water quality of Turag river may not be in a position to sustain the aquatic life and not suitable for using domestic purpose. This is indicated by the very low dissoloved oxygen (DO) levels and other measured parameters in the river. The maximum recorded values of $\mathrm{pH}$, color, turbidity, biochemical oxygen demand (BOD5), hardness, total dissolved solids (TDS), chloride (Cl-), carbondi-oxide (CO2) and chemical oxygen demand (COD) were $7.1 \mathrm{mg} / \mathrm{L}, 625 \mathrm{ptcu}$, 97.2, $4.65 \mathrm{mg} / \mathrm{L}, 1816 \mathrm{mg} / \mathrm{L}, 676 \mathrm{mg} / \mathrm{L}, 5 \mathrm{mg} / \mathrm{L}, 15.5$, and $78 \mathrm{mg} / \mathrm{L}$, respectively. The maximum concentration of turbidity, BOD, hardness, TDS, and COD found in the Turag river is much higher than the standard permissible limit. The study also provides evidence that local communities are suffering from a variety of health problems including skin, diarrhea, dysentery, respiratory illnesses, anemia and complications in childbirth. Yellow fever, cholera, dengue, malaria and other epidemic diseases are also available in this area. Furthermore, the people are suffering by the odor pollution and respiratory problems. 
Abul, Mazlin, Mohd, Muhd, Goh, Rahmah \& Muhammad (2015) assessed the impact of polluted river water in the context of environmental risk as well as ecological risk. A rigorous survey has done on the existing literature of environmental risk and water pollution in respect of ecological, social and economic boundaries in the river basin area. The review findings concluded that polluted river water is seriously caused for hampering of the Sustainable Development (SD) especially in the context of sustainable development, ecosystems change, sustainable livelihoods, land cover, ecosystems, environmental sensitivity, biodiversity and geodiversity as well as social and economic arena in a river basin over the world. The study has drawn Necessary recommendations \& policy considerations which would be raised and highlighted for implementation by policy and decision makers throughout the study.

Similarly, Isola (2014) explored the impact of oil production on human condition in Nigeria. The paper used environmental degradation, life expectancy, and infant mortality rate as proxies of human condition. The data were obtained from the statistical bulletin of the Central Bank of Nigeria and World Development Indicator. The study covered 1980 to 2012. Vector autoregressive (VAR) model and variance decomposition analysis were explored. Three striking results were reported: (i) oil production of the first period positively impacted environmental degradation, while it was negative in the second period; (ii) Its first period lag has positive relationship but second period lag has negative relationship with life expectancy; and (iii) The variance decomposition analysis showed that oil production worsened environmental degradation and adversely impacted on infant mortality rate, while it positively affected life expectancy. Two major recommendations emanated from the study: (i) since oil production has a negative impact on human condition in Nigeria, efforts should be made to control carbon emission from fuel by ending gas flaring, especially in the Niger Delta region; and (ii) Government should look for means to channel their efforts into sustainable policies that would aim at transforming some of the largess from the oil sector into the health sector, as well as into the provision of infrastructural and life enhancing facilities like good roads, portable water, and so on. These can help to enhance life expectancy beyond its current stagnant state. All these as suggested will make the oil sector to have huge positive impact on human condition.

Sajini (2013) reviewed socio-economic problems of oil exploration and exploitation in Nigeria's Niger Delta. Since the 1970s, Nigeria's socioeconomic and political fortune have been intricately linked with oil explorations, with petroleum oil providing about 95 percent of exports 
earnings and accounting for over 80 percent of government revenue as well as generating over 40 percent of the GDP. It is revealing to note that the oil that generate these numerous benefits to Nigeria come solely from the Niger Delta region. However, the paradox is that while oil from Niger Delta has generated massive economic and social transformations of many parts of the country on the one hand, it has resulted into unparalleled damage to the Niger Delta environment thus inducing multi-faceted problems in the region. This paper examines the social and economic problem of oil exploration and exploitations in the Niger Delta region. The paper identified abject poverty, deprivation, social conflict, occupational dislocation, ill health, etc. as some of the social and economic problems resulting from environmental pollution associated with oil extractions activities in the Niger Delta. The paper also made recommendations.

In the same vein, Olujimi, Adebayo, and Sogbon (2011) investigated environmental implications of oil exploration and exploitation in the coastal region of Ondo State, Nigeria: A regional planning appraisal. In the light of this, the paper appraises the implications of oil exploration and exploitation in the coastal region of Ondo State. Data used in the paper were obtained through physical verification, regular observations, constant monitoring, documentation and records of oral history and administration of questionnaire in some selected settlements in the region. The paper highlighted several direct environmental and associated problems that emanated from oil exploration and exploitation in the region. The problems identified among others include large-scale environmental pollution and degradation of agricultural land which serves as source of income for the people coupled with social unrest arising from unpaid claims of compensation and lack of concern for the people in the exploration area. The paper advocates for oil spill management plan, control and clearance of spills; giving concessions to indigenous oil companies during bidding process by granting licenses to operate in the Niger-Delta region; adoption of long-term monitoring and surveillance mechanism; continuous provision of infrastructure for the host communities by prospecting oil companies; and development of national oil spill contingency plan among others with a view to guarantee sustainable development of the environment in the region.

Olusiyi (2009) examined the effects of oil spillage on the socio-economic activities of the people and the environment in some communities in the Niger Delta. The objectives are to determine the quantity of oil spilled from pipelines, the area of coverage and to assess the effects of oil spillage on the people, soil and water. Data were collected from both primary and secondary sources. The primary data relied on the administration of structured 
questionnaires; 319 questionnaires were randomly distributed to a sample population (household heads), with 302 retrieved. Secondary data were sourced from published materials. Also, soil samples from four locations and water samples from five locations were collected to determine the $\mathrm{pH}$ value of the water, the presence and concentration of heavy metals in the soil and the total hydrocarbon content (THC) of water. Soil and water samples were analyzed using the atomic absorption spectrophotometer and gravimetric methods for soil and water, respectively. There was a strong relationship between the volume of oil spilled and the area coverage. Laboratory soil analysis from sampled communities showed a higher concentration of heavy metals (chromium, lead, arsenic, etc.) above the World Health Organization (WHO) permissible levels as well as the figure for controlled site. The study therefore recommended that environmental laws should be strictly adhered to and compensation should be adequately and promptly paid to the communities, and remedial action should be speedily undertaken whenever there are spills.

Asia, Jegede, Jegede, Ize-Iyamu and Akpasubi (2007) examined the effects of petroleum exploration and production operations on the heavy metal contents of soil and groundwater in the Niger Delta. Soil and water samples obtained from four sampling points; around an oil well head, flare site, waste pit and effluent discharge point in an exploration area in the Niger Delta were analyzed for their heavy metal contents. The results showed that the amount of lead present in the soil ranges from $3.40-99.40 \mathrm{mg} / \mathrm{kg}$, copper values were in the range of $5.10-49.30 \mathrm{mg} / \mathrm{kg}$, Nickel concentration vary from $1.60-$ $13.80 \mathrm{mg} / \mathrm{kg}$, values for cadmium, iron, zinc, and chromium were $0.04-0.95$ $\mathrm{mg} / \mathrm{kg}, 536.00-12,872.00 \mathrm{mg} / \mathrm{kg}, 11.1-274.00 \mathrm{mg} / \mathrm{kg}$ and $1.30-165.00$ $\mathrm{mg} / \mathrm{kg}$ respectively. Apart from zinc and nickel, all other heavy metals were higher than the toxicity limits for heavy metals in natural soil; this implies pollution of the soil by heavy metals. Also, the waters were found to be polluted by lead, the $\mathrm{pH}$ of the water samples was found to deviate significantly from Department of Petroleum Resources and World Health Organization DPR limits and W.H.O. standard for potable water. This also implies pollution. Remediation measures were suggested so as to render the soil and ground water fit for use. 


\section{Presentation of Results}

\subsection{Hypothesis $1\left(\mathrm{Ho}_{1}\right)$}

There is no significant relationship between the role of the Nigeria State, multinational oil companies and the community leadership and the negative effect of water pollution on the health of the people of the oil-bearing communities in Bayelsa State.

Table 1: Chi-square analysis of questionnaire for the relationship between the role of stakeholders and negative effect of water pollution on the health of the people

\begin{tabular}{|c|c|c|c|c|c|c|c|}
\hline Items & Yes & No & Total & Df & $\mathrm{X}^{2}$-cal. & $\mathrm{X}^{2}$-cri. & Decision \\
\hline 1 & 57 & 43 & 385 & \multirow{5}{*}{1} & \multirow{5}{*}{8.19} & \multirow{5}{*}{3.84} & \multirow{5}{*}{$\begin{array}{l}\mathrm{Ho}_{1} \text { is } \\
\text { Rejected }\end{array}$} \\
\hline 2 & 51 & 49 & 385 & & & & \\
\hline 3 & 45 & 56 & 385 & & & & \\
\hline 4 & 61 & 39 & 385 & & & & \\
\hline 5 & 42 & 58 & 385 & & & & \\
\hline
\end{tabular}

Source: Field Work 2018

$\mathrm{P}>0.05$

In table 1 above, with alpha level of 0.05 , the degree of freedom (DF) of 1 , the critical value is 3.84 while calculated value is 8.19 . Since the calculated value is greater than the critical value, the null hypothesis is therefore rejected. This shows that there is a significant relationship between the role of the Nigeria State, multinational oil companies and the community leadership and the negative effect of water pollution on the health of the people of the oil-bearing communities in Bayelsa State.

Hypothesis $2\left(\mathrm{Ho}_{2}\right)$

There is no significant relationship between the role of the Nigeria State, multinational oil companies and the community leadership and the negative effect of water pollution on the occupation/economic status of the people of the oil-bearing communities in Bayelsa State. 
Table 2: Chi-square analysis of questionnaire for the relationship between the role of stakeholders and negative effect of water pollution on the occupation/economic status of the people

\begin{tabular}{|l|l|l|l|l|l|l|l|}
\hline Items & Yes & No & Total & Df & $\mathbf{X}^{2}$-cal. & $\mathbf{X}^{2}$-cri. & Decision \\
\cline { 1 - 4 } & 65 & 35 & 385 & & & & \\
\cline { 1 - 4 } & 48 & 52 & 385 & & \multirow{2}{*}{8.67} & 3.84 & $\begin{array}{l}\text { Ho2 is } \\
\text { Rejected }\end{array}$ \\
\hline 3 & 51 & 49 & 385 & & & & \\
\hline 5 & 45 & 55 & 385 & & & & \\
\hline
\end{tabular}

Source: Field Work 2018

$\mathrm{P}>0.05$

In table 2 above, with alpha level of 0.05 , the degree of freedom (DF) of 1 , the critical value is 3.84 while calculated value is 8.67 . Since the calculated value is greater than the critical value, the null hypothesis is therefore rejected. This shows that there is a significant relationship between role of the Nigeria State, multinational oil companies and the community leadership and the negative effect of water pollution on the occupation/economic status of the people of the oil-bearing communities in Bayelsa State.

Hypothesis $3\left(\mathrm{Ho}_{3}\right)$

There is no significant relationship between the role of the Nigeria State, multinational oil companies and the community leadership and the negative effect of water pollution on the livelihood standard/poverty level of the people of the oil-bearing communities in Bayelsa State.

Table 3: Chi-square analysis of questionnaire for the relationship between the role of stakeholders and negative effect of water pollution on the livelihood standard/poverty level people in Bayelsa State

\begin{tabular}{|c|c|c|c|c|c|c|c|}
\hline Items & Yes & No & Total & Df & $\mathrm{X}^{2}$-cal. & $\mathrm{X}^{2}$-cri. & Decision \\
\hline 1 & 66 & 34 & 385 & \multirow{4}{*}{1} & \multirow{4}{*}{35.81} & \multirow{4}{*}{3.84} & \multirow{4}{*}{$\begin{array}{l}\mathrm{Ho}_{3} \text { is } \\
\text { Rejected }\end{array}$} \\
\hline 2 & 43 & 57 & 385 & & & & \\
\hline 3 & 36 & 64 & 385 & & & & \\
\hline 4 & 75 & 25 & 385 & & & & \\
\hline
\end{tabular}




\begin{tabular}{|l|l|l|l|l|l|l|l|}
\hline 5 & 55 & 45 & 385 & & & & \\
\hline
\end{tabular}

Source: Field Work 2018

$\mathrm{P}>0.05$

In table 3 above, with alpha level of 0.05 , the degree of freedom (DF) of 1 , the critical value is 3.84 while calculated value is 35.81 . Since the calculated value is greater than the critical value, the null hypothesis is therefore rejected. This shows that there is a significant relationship between the role of the Nigeria State, multinational oil companies and the community leadership and the negative effect of water pollution on the livelihood standard/poverty level of the people of the oil-bearing communities in Bayelsa State.

\subsection{Discussion of Results}

The study showed that there is a significant relationship between the role of the Nigeria State, multinational oil companies and the community leadership and the negative effect of water pollution on the health of the people of the oil-bearing communities in Bayelsa State. This is evident to the fact that local communities are suffering from a variety of health problems including skin, diarrhea, dysentery, respiratory illnesses, anemia, complications in childbirth, Yellow fever, cholera, dengue, malaria and other epidemic diseases and respiratory problems caused by oil exploration in the region (Nizel and Nazrul 2015).

This finding is in congruence with Afonughe and Mukoro (2017) who reported that expectedly, oil production supposed to translate into economic prosperity for these "fortunate" states and communities but sadly, the reverse is the case. There have been cries of marginalization, environmental pollution, climate change, unemployment, prevalence of sicknesses and diseases due to the activities of crude oil exploitation in these oil producing communities. They added that the activities of crude oil exploration companies are impacting negatively on the development of the communities; farmlands have been rendered infertile, thereby hampering agricultural output and productivity, rivers and streams have been polluted leading to the reduction in the availability of fishes and other aquatic products, resulting in untold hardships being experienced by the indigent of theses oil-bearing communities in Niger Delta Region.

The study showed that there is a significant relationship between role of the Nigeria State, multinational oil companies and the community leadership and the negative effects of water pollution on the occupation/economic status of the people of the oil-bearing communities in Bayelsa State. One plausible explanation to this finding is that oil exploitation, through environmental 
degradation has depleted the fishing and farming output, resulting in the subsequent loss of income base, thereby accentuating poverty, which in turn created divisive tendencies leading to endemic social conflict in the region (Abosede 2017).

This finding concord with Afonughe and Mukoro (2017) who asserted that expectedly, oil production supposed to translate into economic prosperity for these "fortunate" states and communities but sadly, the reverse is the case. There have been cries of marginalization, environmental pollution, climate change, unemployment, prevalence of sicknesses and diseases due to the activities of crude oil exploitation in these oil producing communities. They added that the activities of crude oil exploration companies are impacting negatively on the development of the communities; farmlands have been rendered infertile, thereby hampering agricultural output and productivity, rivers and streams have been polluted leading to the reduction in the availability of fishes and other aquatic products, resulting in untold hardships being experienced by the indigent of theses oil-bearing communities in Niger Delta Region.

The study revealed that there is a significant relationship between the role of the Nigeria State, multinational oil companies and the community leadership and the negative effect of water pollution on the livelihood standard/poverty level of the people of the oil-bearing communities in Bayelsa State. This finding may be attributed to the fact that crude oil pollution has adverse and severe socio-economic impacts on fish farming that is the main occupation of the people leading to increased fish mortality rates, reduced yield and general poor quality of cultured fishes (Akankali and Nwafili 2017).

This finding concord with Afonughe and Mukoro (2017) who asserted that expectedly, oil production supposed to translate into economic prosperity for these "fortunate" states and communities but sadly, the reverse is the case. There have been cries of marginalization, environmental pollution, climate change, unemployment, prevalence of sicknesses and diseases due to the activities of crude oil exploitation in these oil producing communities. They added that the activities of crude oil exploration companies are impacting negatively on the development of the communities; farmlands have been rendered infertile, thereby hampering agricultural output and productivity, rivers and streams have been polluted leading to the reduction in the availability of fishes and other aquatic products, resulting in untold hardships being experienced by the indigent of theses oil-bearing communities in Niger Delta Region. 


\subsection{Methodology}

The study adopted descriptive survey research design. The use of descriptive survey design is predicated on the fact that the researcher used a questionnaire to obtain information on the variables under study from the sample that was drawn from the population. This design enables the researcher to collects detailed information that describe existing phenomena in their natural setting, make comparism and evaluation, as well as identify problems or justify current conditions and practices as well as determine what others are doing with similar problems to solutions and benefits from experience making future plans and decisions.

The population of the study comprised of all the 36 oil-bearing communities in Bayelsa State, while the sample of the study consists of four hundred (400) adult. The four hundred adults were selected from eight oil-bearing communities in Bayelsa State using Stratified and simple random sampling techniques. The instrument that was used for data collection is the oil production and water pollution Questionnaire was used as an instrument for data collection which is made up two sections and it contains nineteen (15) items which enabled the researcher to spread the questions/items across the independent and intervening variables The data were collected by the researcher and eight (8) research assistants and all the research hypotheses were tested for significant difference at 0.05 level of significance using ChiSquare.

\section{Conclusions/Recommendation}

Undoubtedly, oil production has over the decades provided critical inputs for the expected development agenda at the different levels of government in Nigeria. The rather unending quest for more development has also made the exploitation and utilization of the rich oil resource glaringly inevitable in Nigeria's Niger Delta. While the ensuing and continuous developmental efforts engendered mainly by oil production activities remain common-place and therefore a reality in Nigeria, it is the poor management of the negative out-comes of the use and misuse of the oil resource for development purposes that is the crux of the matter. To this end, the study based on its major findings, concludes that since there is a significant relationship between the role of the Nigerian State, multinational oil companies and the community leadership and the negative effects of water pollution on the health of the people of the oil-bearing communities in Bayelsa State, the collective roles of the three stakeholders above have negatively impacted on the health status of the people of the oil-bearing communities. Besides. in view of the fact that 
there is a significant relationship between the role of the Nigerian State, multinational oil companies and the community leadership and the negative effect of water pollution on the occupation/economic status of the people of the oil-bearing communities in Bayelsa State, it is concluded that that the collective roles of the three stakeholders above have negatively impacted on the occupation/economic status of the people of the oil-bearing communities. To the extent that there is a significant relationship between the role of the Nigerian State, multinational oil companies and the community leadership and the negative effect of water pollution on the livelihood standard/poverty level of the people of the oil-bearing communities in Bayelsa State, it is equally concluded that the collective roles of the three stakeholders above have negatively impacted on the livelihood standard/poverty of the people of the oil-bearing communities.

In the light of the findings and conclusion of the study, the following recommendations are made: the multi-layered levels of the government should formulate and genuinely implement policies that will mitigate the effects of water pollution on the health, economic and livelihood status of the people in the Niger Delta Region; the multinational oil conglomerates should be truly committed to integrated policies and strategies that will close the developmental gaps and proactively enhance the capacity of the people of the Niger Delta to live decent and fulfilled lives and the community leaders in the Niger Delta should sincerely partner and cooperate with both the multilayered levels of government and the oil conglomerates in order to actualize the yearnings and aspirations of the people.

\section{References}

Abosede, Omowumi B. 2017. "Effect of Oil Exploitation on the Socio-Economic life of the Ilaje-Ugbo people of Ondo State, Nigeria." Journal of Sustainable Development in Africa 12 (5): 61-84.

Abul, B. B., Mazlin, B. M., Mohd, E. T., Muhd, B. G., Goh, C. T., Rahmah, E. \& Muhammad, R. R. 2015. "The environmental risk and water pollution: A review from the river Basins around the World." American-Eurasian Journal of Sustainable Agriculture 7 (2): 126-136.

Afonughe, Irikefe O., and Mukoro, Akpomivir. 2017. "The Impact of Oil Exploitation on the Socio-Economic Life of Orogun Community, an Oil Producing Community in Delta State, Nigeria." American Journal of Environmental and Resource Economics 2 (2): 73-79. 
Akankali, J. A. and Nwafili, S. A. 2017. "The Impact of Crude Oil Pollution on Aquaculture Nigerian." Journal of Fisheries and Aquaculture 5 (1): 87-94.

Asia, I. O., Jegede, S. I., Jegede, D. A., Ize-Iyamu O. K. and Akpasubi, E. B. 2007. "The Effects of Petroleum Exploration and Production Operations on the Heavy Metals Contents of Soil and Groundwater in the Niger Delta." International Journal of Physical Sciences 2 (10): 271-275.

Cunningham, H. 2016. The Oil Industries and Water Pollution in Nigeria. London: Free Press.

Ejumudo, Kelly-Bryan 0. 2011. Managing the Problem of Water Pollution in the Niger Delta Region. Lagos: Thompson Publishers.

Ejumudo, Kelly-Bryan 0. 2015. "Managing the Development/Environment Dilemma: The Global Challenge." Journal of Development Alternatives and Area Studies 31 (2): 18-43.

Field, Martha K. 2015. Environmental economics: An introduction. New York: McGraw-Hill.

Humphrey, D. 2015. A Review of Nigeria's Petroleum Industry and Its Negative Impact on Niger Delta Region. London: Free Press.

Imoukhuede, O. B. and Afuye, G. G. 2016. "Water Pollution and its effect on Water Consumption in Akure." International Journal of Environmental and Agriculture Research 2 (5): 1-5.

Isola, W. A. 2014. "Impact of Oil Production on Human Condition in Nigeria." Munich Personal REPEC Archive 1-22.

King, Godwin O. 2016. Issues in Oil Exploration and Exploitation in Niger Delta Region. London: Free Press.

Mehtab, H., Muhammad, F. M., Asma, J., Sidra, A., Nayab, A., Sharon, Z. and Jaweria, H. 2017. "Water Pollution and Human health." Journal of Environmental Risk Assessment 1 (3): 16-19.

Narayanam, P. 2017. Environmental Pollution: Principles, Analysis and Control. New Delhi: CBS Publishers. 
Nizel, J. H. and Nazrul, I. 2015. "Water Pollution and its Impact on the Human Health." Journal of Environment and Human 2 (1): 36-46.

Olujimi, Julius B, Bayode, Emmanuel A and Sogbon, Odunwole 2011. "Environmental implications of oil exploration and exploitation in the coastal region of Ondo State." Journal of Geography and Regional Planning 4 (3): 110121.

Olusiyi, Ipingbemi 2009. "The Effects of Oil Spillage on the Socio-Economic Activities of the People and the Environment in some Communities in the Niger Delta." Journal of Integrative Environmental Science 6 (1): 7-23.

Osumgborogwu, I. E., Okoro, F. C and Oduaro, I. J. 2018. "Social effect of crude oil production activities in Egbema, Imo State." Asian Research Journal of Arts \& Social Sciences 3 (2): 1-7.

Rafia, Afroz and Muhammad, Mehedi M. 2014. "Sources of water pollution, water resource policies and challenges sage." Journal of Environment and Urbanization 5 (1): 63-81.

Sajini, Faith I. 2013. "Socio-economic problems of Oil Exploration and exploitation in Nigeria's Niger Delta." Journal of Energy Technologies and Policy 3 (1): 76-80.

Tietenberg, Tom 2015. Environmental and Resource Economics. London: Pearson Education. 